\title{
Subjective Dimension of Mental Health: Psychometric Properties of the Ukrainian Version of Orientation to Happiness Scale
}

\author{
Iryna KRYVENKO \\ Ukrainian Catholic University, Lviv, Ukraine \\ i.horbal@ucu.edu.ua \\ Galyna PETRYK \\ Ukrainian Catholic University, Lviv, Ukraine \\ petryk-h@ucu.edu.ua
}

\begin{abstract}
According to Seligman's concept of authentic happiness, people tend to choose one of three different ways to be happy: through pleasure, through engagement, and through meaning. This paper addresses the development of Ukrainian adaptation of the 18-item three-dimensional Orientation to Happiness Scale (Peterson, Park, Seligman, 2005) and the examination of its psychometric properties. On the results of PCA $(N=468)$ a three-factor structure due to a theoretical framework was confirmed with Cronbach's alphas between .65 and .80. A satisfactory test-retest stability for each sub-scale in the 4-week period $(N=123)$ and the construct validity were revealed. During criterion-validity analysis statistically significant differences ( $p$ $<.05)$ in orientations to happiness were shown for religious and non-religious people, reflecting the specificity of connections between happiness, faith, and religious behaviour.
\end{abstract}

Keywords: orientations to happiness; psychometric properties; well-being;

JEL Codes: I10; I31; Z13;

DOI: http://doi.org/10.24818/ejis.2019.07

\section{Introduction}

Although the questions on well-being and happiness were raised many centuries before, since Martin Seligman became the APA President in 1998, the focus on positive aspects of mental health started being much clearer. Happiness studies became important not only for philosophers and other humanities but for specialists in wide areas that are called up for making life better. Together with other social practices and services, psychology is one of a kind. Numerous researches show that the changes of happiness level are much on the influence of life events such as marriage (Clark et al., 2008) or divorce (Lucas, 2005; Gardner and Oswald, 2006), employment (Chi et al., 2006) or unemployment (Lucas et al., 2004; Clark, 2006), lottery winning (Diener and Biswas-Diener, 2002) etc. However, these circumstances change a person's well-being dramatically but briefly; soon we get used to new conditions and turn back to the basic level of well-being.

On the contrary, correlations of happiness indicators with high extroversion, low neuroticism (Hayes and Joseph, 2003; Gomez et al., 2012), openness to experience (Schimmack et al., 2004), sense of control over personal life, self-confidence (Knyazyeva, 2011) and self-esteem (DeNeve and Cooper, 1998) are revealed; thus, it is connected with socially admired traits. Experience of subjective well-being is followed by social activity, leadership predispositions, independence aspiration (Kologryvova, 2008). Moreover, wellbeing measures are linked to optimism (Hutz et al., 2014), positive self-attitude (Zelinska, 
2012) and self-satisfaction (Cummins and Nistico, 2002), good mental (Kiecolt-Glaser et al., 2002) and physical health (Danner et al., 2001). Thus, it is urgent to have good instruments for measuring happiness experience in order to get information for diagnostics and anticipation of heavy stress and negative mental health outcomes in wide areas of practice like medicine, social work, education, psychology etc.

Although many happiness questionnaires in modern positive psychology exist, a big amount of them cannot pretend to be valid and reliable mainly because of the methodological ambiguity of happiness concept. Moreover, even a smaller number of such measurement instruments is in Ukrainian, adapted to language and culture specificity that makes it difficult to provide well-being studies among the population.

One of the most contemporary ways of solving the first methodological problem is reflected by Seligman's concept of authentic happiness (2002a, b). Based on it, Orientations to Happiness Scale was created, which has high indicators of validity and reliability and measures the most typical way that person chooses for being happy (Peterson et al., 2005).

\section{Orientations to Happiness}

The famous happiness formula by Seligman is $\mathrm{H}=\mathrm{S}+\mathrm{C}+\mathrm{V}$ which means that happiness $(\mathrm{H})$ is defined by the set range $(\mathrm{S})$, circumstances $(\mathrm{C})$ and voluntary control (V) (Seligman, 2002a). Thus, although $50 \%$ of happiness is completely out of person's control because it depends on genes and 10\% more are influenced by the external circumstances of life, the rest $40 \%$ of happiness is determined by person's activities and efforts. By making decisions and labouring, a person chooses directions where to move in for getting positive experience as a result. Thinking on hedonists' and eudaemonists' discussion lasting for many centuries, Peterson et al. (2005) emphasize that there is actually no controversy between pleasure aspirations and virtues embodiment, those are only different sources of happiness. One more such a source is engagement which is a concept emerged from the "flow" theory (Csikszentmihalyi, 2000). Due to it, flow is a psychological state that accompanies a person's really exciting activity which he/she enjoys, is fully absorbed in losing the sense of space and time and feels inspired as a result.

Thus, the theoretical construct of authentic happiness provides us with the three orientations (ways, paths) to happiness that is the pursuit of pleasure, engagement, and meaning. A pleasant life is about maximizing positive and minimizing negative experience, the path promoted in hedonistic tradition. Engaged life is focused on reaching a state of flow while being involved in some activity. Finally, meaningful life as the third happiness orientation is based on eudaemonic view on happiness and appeals to 'using your signature strengths and virtues in the service of something much larger than you are' (Seligman, 2002a, p. 262), having a great purpose in life, transcendental experience etc. Although only this last orientation to happiness Seligman calls true, "essential" happiness, empirical evidence showed that they are rather not incompatible, but complementary and can be pursued simultaneously. A full life is meant to be where people use all three ways to happiness, while empty life is interpreted by not endorsing either of them (Peterson et al., 2005). 


\section{The Orientation to Happiness Scale}

Orientations to Happiness Scale (OTH) (Peterson et al., 2005) was created by choosing statements with the highest loadings among 36 in the essential version. This is an 18-item self-report questionnaire for the measurement of the extent to which three paths to happiness (pleasure, meaning, and engagement) are chosen by a person. Despite this, each of the measured sub-scales is quite an independent indicator having different connections with well-being indexes and personality traits.

The sub-scale "pleasure" measures the pursuit of momentary pleasures like a result of buying new clothes, visiting cinema or eating chocolate. That is how happiness is defined in terms of hedonism. This sub-scale correlates with positive affect and life satisfaction (Diener et al., 2009); however, it predicts satisfaction with life for short periods of time. Due to hedonic treadmill theory, neither good nor bad events in our life change some basic level of happiness, soon a person gets used to what has happened (Shane, 2007). Accordingly, the positive effect of quick delight decays soon together with the level of life satisfaction as a result. That is true for both psychological (Seligman, 2002b; Steger et al., 2008), and physical (Oishi et al., 2001) pleasures. Speaking of personality traits, the sense of humour is mostly correlated with this orientation to happiness (Peterson et al., 2007).

The sub-scale "meaning" measures person's orientation to search of purpose of every activity that helps to set clear goals, increase well-being and improve social communications (Baumeister and Vohs, 2002) (it can be made via volunteering, spirituality, helping other people etc. (Peterson et al., 2005)). The sense of meaning correlates positively with happiness indexes, life satisfaction, positive emotions, and negatively with depressive and other psychopathological symptoms (Mascaro and Rosen, 2006; Park et al., 2010). From among personality traits, this orientation is mostly observed among people with high religiousness/spirituality (Peterson et al., 2007).

The sub-scale "engagement" measures the extent to which a person is inspired by the activity. It is found out that the flow state may equally appear while doing an activity which enhances personal growth (Waterman, 1993) and which aims to feel pleasure, like, e.g., videogames (Hsu and Lu, 2004). Again, this state correlates positively with subjective wellbeing (Csikszentmihalyi, 2000). Moreover, doesn't matter how long the activity is lasting, flow is a stronger predictor of longer subjective well-being than momentary pleasures (Huta and Ryan, 2010). Those respondents who have experienced flow in their lives declare that they have felt more satisfied retrospectively, but not at the time when providing the activity (Carli et al., 1988). Such absorption is able to intensify adaptive personality resources and enhance personal growth enclosing talents and skills. This leads to subjective well-being as well as to fruitfulness and success in the future (Schueller and Seligman, 2010). Csikszentmihalyi (2000) proves that those who usually have flow states are more persistent in different tasks and thus achieve more success. Personality traits that are connected with this orientation to happiness are more diverse and include zest, curiosity, and perseverance (Peterson et al., 2007).

Although orientations to happiness and subjective well-being are expected to be connected, these links are not clear enough. Orientations to happiness correlate differently with happiness measures (Peterson et al., 2005; Avsec et al., 2015; Chan, 2009; Chen et al., 2010; Schueller and Seligman, 2010). Generally, orientations to happiness were proved to be able to predict subjective well-being, although Vella-Brodrick et al. (2009) revealed that even bigger part of it is defined by the personality traits (e.g., life satisfaction and positive affect depend much on the Big Five traits, according to DeNeve and Cooper (1998)): when 
these traits are controlled, the role of orientations to happiness in subjective well-being variance is minimized.

Despite this, a big role of orientations to happiness was proved by the intervention research of Seligman et al. (2005). Participants were asked to write down three good events that happened to them every day during a week. Those events had to reflect one of three orientations to happiness. Every day they also evaluated their subjective well-being level. At the end of the research, those participants who focused mainly on the events which corresponded to their main orientation to happiness have not achieved notable increases of subjective well-being compared to those who stressed the orientation which he/she uses relatively rarely. Such horizons expansion is interpreted as the verification of "full life" hypothesis (Seligman et al., 2005) according to which only a combination of highly developed all orientations to happiness is able to lead to high subjective well-being.

Additionally, many researches have proved that orientations to happiness and correlations of OTH and subjective well-being indexes differ much among cultures (Vella-Brodrick et al., 2009; Kose, 2014; Kenkyu, 2011).

\section{Methodology}

Thus, although the OTH sub-scales context looks quite understandable, many inconsistencies and a big culture diversity were found. This means that Ukrainian culture adaptation of the OTH scale is important for getting a good diagnostic instrument. The aim of the study is to provide a Ukrainian translation of the OTH scale and analyse its psychometric properties - factor structure, reliability, construct, and criteria validity.

Participants. The sample consisted of 468 respondents. Participants were of different sex, 122 men (26\%) and 346 women (74\%), and age (average age 22.92 years, Min = 18, Max $=58, \mathrm{SD}=8.9)$. Nearly $66 \%$ of them described themselves as non-religious, $34 \%$ attributed themselves to some religion. All of them were Ukrainians. 123 randomly chosen respondents, 36 men and 86 women (average age 24.1 years, Min $=18, \operatorname{Max}=42, \mathrm{SD}=$ 7.2) were included into a retest group in 4 weeks after the first poll.

Measures. The Orientation to Happiness (OTH) Scale (Peterson et al., 2005) is an 18-item (6 for every scale) self-report questionnaire using a 5-point Likert scale. Psychometric properties of the OTH Scale were tested on the material of 845 respondents' online replies ( $28 \%$ men and $72 \%$ women). PCA revealed a 3 -factor model describing $53 \%$ of total variance. $\alpha$-Cronbach coefficient for a sub-scale "pleasure" is .82; for "engagement" is .72; for "meaning" is .82 . On the results of correlation and linear regression analyses including OTH Scale, SWLS (Diener et al., 1985) and a number of demographic characteristics it was found out that all three sub-scales predict the life satisfaction index better than demographics $(\beta=-.11 ; p<.05$ for "pleasure"; $\beta=-.17$ and $\beta=-.24 ; p<.001$ for "meaning" and "engagement" respectively). Moreover, the most satisfied according to a regression model are those people who score higher by all OTH sub-scales $\left(\beta=-2,50, \Delta \mathrm{R}^{2}=.006 ; \mathrm{p}\right.$ $<0,05)$ (Peterson et al., 2005). Taking all these results into account, OTH Scale may be considered as a valid questionnaire.

Satisfaction with Life Scale (SWLS) (Diener et al., 1985) is a 5-item self-report 7-point Likert scale which measures the individual's evaluation of satisfaction with life in general. Research has established acceptable psychometric properties for the SWLS (Diener, 1985). In the current study, the Ukrainian translation of SWLS (Horbal, 2016) was used. 
Affective Balance Scale (ABS) is a 10-item scale for assessing positive (5 items) and negative (5 items) affect as indicators of well-being (Bradburn, 1969). In the current study, the Ukrainian translation of SWLS (Semkiv, 2009) was used.

Psychological Well-Being Scale (PWBS) (Ryff and Keyes, 1995) is an 84-item self-report questionnaire consisting of 6 dimensions: autonomy, environmental mastery, personal growth, positive relations with others, purpose in life, self-acceptance. The Ukrainian version of the scale used in the research was created by Karskanova (2011).

Procedure. The cultural adaptation of OTH Scale in Ukraine was implemented by three stages. On the first stage for obtaining of linguistic validity, the procedure of double translation was made. Firstly, two direct translations of the original OTH Scale into Ukrainian were provided by the Ukrainian native speakers with an advanced level of English, and united test-version was created. Secondly, two independent reverse translations of this test-version into English were made by English native speakers with an advanced level of Ukrainian, specialists in behavioural and social sciences. These translations were analysed and compared to the original OTH Scale, following the inconsistencies, and changes in the Ukrainian test-version were made. The final Ukrainian version was discussed with the Ukrainian philologist and final editing were made. On the second stage the empirical research was conducted (November 2017 - May 2018) in paperand-pencil (35\% of respondents) and online (65\% of respondents) forms. On the third stage, psychometric properties of the Ukrainian version of OTH Scale were tested. For control of structural validity factor analysis was performed in case of checking the consistency of the items in the sub-scales. The construct validity of the Ukrainian version of OTH Scale was examined by the analysis of correlations between the questionnaire sub-scales with SWLS, ABS, and PWBS. Criterion validity analysis was led by correlation and comparative analysis of orientations to happiness with demographics and religious orientations. The reliability of Ukrainian translation of the OTH Scale and its separate sub-scales was assessed due to $\alpha$-Cronbach coefficients, inter-correlations between sub-scales and 4-week retest procedure.

\section{Results}

\subsection{Structure validity}

On the results of EFA (principal components analysis with varimax rotation) of Ukrainian translation, a 3 -factor model describes $47.8 \%$ of total variance. Reproduced and residual correlation matrices are distant enough $(\mathrm{Min}=|.38|)$ to consider this model as qualitative.

By its content, the factor model is very close to the authors' version. The factor loadings on the three factors are presented in Table 1. According to the factor loadings in a hierarchical factor structure, items No.3, 8, 13, 15, 16, and 18 that form Factor 2, totally reflect a sub-scale "pleasure" in OTH Scale. Other two factors are slightly different from the original.

Item No.9, designed to measure engagement, had a higher loading on meaning. Together with items No.2, 5, 11, 12, and 14 from the sub-scale "meaning" it forms Factor 1. The rest six items, No.1, 4, 6, 7, 10, and 17 go into Factor 3, five of which (except item No.17 which was originally designed to measure meaning) are included in a sub-scale "engagement". None of the remaining items showed cross-loadings (less than .25 for each item). 


\subsection{Internal and retest reliability}

Due to the differences found between the original and translated version of OTH Scale, the reliability test was made for both those structures in Ukrainian sample. Comparing the $\alpha$ Cronbach coefficients for sub-scales "meaning" and "engagement", they were higher for a received in PCA model than for original structure (.80 compared to .76 for meaning, .65 compared to .57 for engagement). For a sub-scale "pleasure" $\alpha$-Cronbach coefficient is .73 (see Table 2). Thus, the retrieved from the EFA OTH model for Ukrainian respondents is more reliable.

Comparing the results to the original's (Peterson et al., 2005) and other adaptations (in Turkish (Saricam and Canatan, 2015), in French (Martin-Krumm et al., 2015), in German (Ruch et al., 2010)) $\alpha$-Cronbach coefficients the conclusion of the homogeneity of the scale may be done.

Randomly selected 123 participants from the main sample were polled by the Ukrainian version of OTH Scale once more after 4 weeks. As there was found, no normal distribution in a first test $(\mathrm{p}<.05)$ unless it was found in 4 weeks retest $(\mathrm{p}>.05)$, non-parametric criteria were used for retest reliability analysis.

Table 1. Factor loadings received from the principal components' analysis with varimax rotation of the Ukrainian version of OTH Scale $(N=468)$

\begin{tabular}{|c|c|c|c|}
\hline Item (Peterson, Park, Seligman, 2005, p. 31-32) & $\begin{array}{l}\text { Factor } 1 \\
\text { Meaning }\end{array}$ & $\begin{array}{l}\text { Factor } 2 \\
\text { Pleasure }\end{array}$ & $\begin{array}{l}\text { Factor } 3 \\
\text { Engagement }\end{array}$ \\
\hline $\begin{array}{l}\text { 01. Regardless of what I am doing, time passes very } \\
\text { quickly. }\end{array}$ & .078 & .028 & $.549 *$ \\
\hline 02. My life serves a higher purpose. & $.794 *$ & .003 & .145 \\
\hline $\begin{array}{l}\text { 03. Life is too short to postpone the pleasures it can } \\
\text { provide. }\end{array}$ & .148 & $.611^{*}$ & .022 \\
\hline $\begin{array}{l}04 \text {. I seek out situations that challenge my skills and } \\
\text { abilities. }\end{array}$ & .161 & .221 & $.536^{*}$ \\
\hline $\begin{array}{l}\text { 05. In choosing what to do, I always take into account } \\
\text { whether it will benefit other people. }\end{array}$ & $.628 *$ & -.034 & .107 \\
\hline $\begin{array}{l}\text { 06. Whether at work or play, I am usually "in a zone" } \\
\text { and not conscious of myself. }\end{array}$ & -.011 & -.031 & $.656^{*}$ \\
\hline 07. I am always very absorbed in what I do. & .110 & .208 & $.583 *$ \\
\hline 08. I go out of my way to feel euphoric. & -.014 & $.580 *$ & .308 \\
\hline $\begin{array}{l}\text { 09. In choosing what to do, I always take into account } \\
\text { whether I can lose myself in it. }\end{array}$ & $.518^{*}$ & -.001 & .058 \\
\hline $\begin{array}{l}\text { 10. I am rarely distracted by what is going on around } \\
\text { me. }\end{array}$ & -.083 & -.163 & $.547 *$ \\
\hline $\begin{array}{l}\text { 11. I have a responsibility to make the world a better } \\
\text { place. }\end{array}$ & $.790 *$ & .058 & -.011 \\
\hline 12. My life has a lasting meaning. & $.788 *$ & .055 & -.018 \\
\hline $\begin{array}{l}\text { 13. In choosing what to do, I always take into account } \\
\text { whether it will be pleasurable. }\end{array}$ & .191 & $.659 *$ & -.007 \\
\hline 14. What I do matters to society. & $.694 *$ & .235 & .051 \\
\hline $\begin{array}{l}\text { 15. I agree with this statement: "Life is short - eat } \\
\text { dessert first.", }\end{array}$ & -.025 & $.645^{*}$ & .080 \\
\hline 16. I love to do things that excite my senses. & .015 & $.626 *$ & .313 \\
\hline $\begin{array}{l}\text { 17. I have spent a lot of time thinking about what life } \\
\text { means and how I fit into its big picture. }\end{array}$ & .104 & .218 & $.485^{*}$ \\
\hline 18. For me, the good life is the pleasurable life. & -.070 & $.709 *$ & -.113 \\
\hline
\end{tabular}

Note. * Location of items on factors.

Source: Authors' computation 
Table 2. $\alpha$-Cronbach coefficients for Ukrainian version of OTH Scale compared to original and other cultural adaptations

\begin{tabular}{|l|l|l|l|l|l|}
\hline Sub-scale & $\begin{array}{l}\text { Ukrainian, } \\
\mathbf{N}=\mathbf{4 6 8}\end{array}$ & $\begin{array}{l}\text { Original, } \\
\mathrm{N}=845\end{array}$ & $\begin{array}{l}\text { German, } \\
\mathrm{N}=5326\end{array}$ & $\begin{array}{l}\text { French, } \\
\mathrm{N}=271\end{array}$ & $\begin{array}{l}\text { Turkish, } \\
\mathrm{N}=489\end{array}$ \\
\hline Pleasure & $\mathbf{. 7 3}$ & .82 & $>.63$ & .67 & .67 \\
\hline Engagement & $\mathbf{. 5 7 * / . 6 5 * *}$ & .72 & .63 & .61 & .66 \\
\hline Meaning & $\mathbf{. 7 6 * / . 8 0 * *}$ & .82 & .76 & .92 & .79 \\
\hline
\end{tabular}

Notes. ${ }^{*} \alpha$-Cronbach coefficient for Ukrainian translation of OTH Scale with the same item structure that in the parent model. ${ }^{* *} \alpha$-Cronbach coefficient for Ukrainian translation of OTH Scale using model retrieved after PCA.

Source: Authors' computation

Spearman rank correlation results are shown in Table 3. Statistically significant correlations for each of the sub-scales were found within 4 weeks. Wilcoxon matched pairs test revealed the tendency (see Table 3): there were no significant differences between first and repeated testing for every sub-scale.

Table 3. Retest reliability indexes of the Ukrainian version of OTH Scale $(\mathrm{N}=123)$

\begin{tabular}{|l|l|l|l|}
\hline Statistical criterion & Pleasure & Engagement & Meaning \\
\hline Spearman rank correlation $(\mathrm{R})$ & $\begin{array}{l}.79 \\
\mathrm{p}<.001\end{array}$ & $\begin{array}{l}.81 \\
\mathrm{p}<.001\end{array}$ & $\begin{array}{l}.73 \\
\mathrm{p}<.001\end{array}$ \\
\hline Wilcoxon matched pairs test $(\mathrm{T})$ & $\begin{array}{l}726 \\
\mathrm{p}=.230\end{array}$ & $\begin{array}{l}688 \\
\mathrm{p}=.212\end{array}$ & $\begin{array}{l}694,5 \\
\mathrm{p}=.527\end{array}$ \\
\hline
\end{tabular}

Source: Authors' computation

\subsection{Construct validity}

To examine the semantic content of the Ukrainian version of OTH Scale the constructs of life satisfaction, positive and negative effect, and psychological well-being dimensions were chosen. The results of Spearman rank correlation analysis of OTH Scale and SWLS, ABS and PWBS are presented in Table 4.

Table 4. Correlation coefficients of OTH Scale with SWLS, ABS and PWBS $(\mathrm{N}=\mathbf{1 2 3})$

\begin{tabular}{|l|c|c|c|}
\hline Sub-scale & Pleasure & Engagement & Meaning \\
\hline Life satisfaction & $.32^{*}$ & .12 & .09 \\
\hline Positive affect & .14 & $.30^{*}$ & $.18^{*}$ \\
\hline Negative affect & $.17^{*}$ & -.10 & .00 \\
\hline Positive relations with others & .02 & -.03 & -.01 \\
\hline Autonomy & .13 & .05 & -.09 \\
\hline Environmental mastery & -.10 & $-.20^{*}$ & -.07 \\
\hline Personal growth & $.23^{*}$ & $.21^{*}$ & $.36^{*}$ \\
\hline Purpose in life & -.12 & -.01 & -.16 \\
\hline Self-acceptance & .13 & -.02 & -.05 \\
\hline
\end{tabular}

Note. $* \mathrm{p}<.05$.

Source: Authors' computation

Statistically significant correlation was found for sub-scale "pleasure" of OTH Scale and general life satisfaction index measured by SWLS $(\mathrm{R}=.32)$. OTH sub-scales have even more diversified links with indexes of positive and negative affect. Namely, "engagement" $(\mathrm{R}=.30)$ and "meaning" $(\mathrm{R}=.18)$ are connected to positive affect, and "pleasure" to negative affect $(\mathrm{R}=.17)$. Among all PWBS components "personal growth" is significantly 
connected with all sub-scales of OTH Scale $(\mathrm{R}=.36$ for "meaning", $\mathrm{R}=.21$ for "engagement", $\mathrm{R}=.23$ for "pleasure"). Finally, a significant relation was found between "engagement" and "environmental mastery".

\subsection{Criterion validity}

Information on religious orientations was taken as a criterion for OTH Scale content assessment. Respondents noted if they believe in God, belong to some religion, how often they visit a church and to which extent they follow religious traditions. The background of such criterion was twofold. Firstly, according to Religious Information Service in Ukraine (2018), Christianity (Orthodox and Greek Catholic) is the major religion in Ukraine. It appeals to the minimization of pleasures and induces search of the sense of life. Secondly, spirituality and religiosity as personal traits are more typical for people with a strong orientation to meaning (Peterson et al., 2007).

Thus, the hypothesis was that religious people tend to have higher rates of meaning, while non-religious score higher in pleasure. Additionally, it was assumed that people who often visit the temple and follow religious traditions score higher in engagement as these activities require a person's concentration and absorption.

On the results of Student t-test, it was found out that non-religious people and those who do not believe in God tend to choose orientation to pleasure more often than religious and believers (see Table 5). However, non-religious people are also more oriented to meaning. The differences in orientation to engagement in a minimal significance level $(p=.05)$ also appeared among these groups: religious people tend to choose this path more often.

Table 5. Means and p-levels of OTH among people with different religious orientations $(\mathrm{N}=123)$

\begin{tabular}{|c|c|c|c|c|}
\hline Sub-scale & $\begin{array}{c}\text { Believers, } \\
\mathrm{n}=71\end{array}$ & $\begin{array}{c}\text { Non-believers, } \\
\mathrm{n}=52\end{array}$ & $\begin{array}{c}\text { Religious, } \\
\mathrm{n}=82\end{array}$ & $\begin{array}{c}\text { Non-religious, } \\
\mathrm{n}=41\end{array}$ \\
\hline \multirow{2}{*}{ Pleasure } & Mean $=19.86$ & Mean $=21.62$ & Mean $=19.56$ & Mean $=21.66$ \\
\hline & \multicolumn{2}{|c|}{$\mathrm{p}=.02$} & \multicolumn{2}{|c|}{$\mathrm{p}=.01$} \\
\hline \multirow{2}{*}{ Engagement } & Mean $=19.68$ & Mean $=18.30$ & Mean $=19.08$ & Mean $=18.22$ \\
\hline & \multicolumn{2}{|c|}{$p=.05$} & \multicolumn{2}{|c|}{$p=.07$} \\
\hline \multirow{2}{*}{ Meaning } & Mean $=19.58$ & Mean $=20.66$ & Mean $=19.40$ & Mean $=20.66$ \\
\hline & \multicolumn{2}{|c|}{$p=.04$} & \multicolumn{2}{|c|}{$\mathrm{p}=.03$} \\
\hline
\end{tabular}

Source: Authors' computation

Pearson correlation analysis (see Table 6 ) revealed that the frequency of visiting temple $(\mathrm{r}$ $=.26)$ and the activity in following religious traditions $(\mathrm{r}=.20)$ correlate positively to subscale "engagement".

Table 6. Correlation coefficients of OTH Scale with characteristics of religious behaviour $(\mathrm{N}=123)$

\begin{tabular}{|l|c|c|}
\hline Subscale & $\begin{array}{c}\text { Frequency of visiting } \\
\text { temple }\end{array}$ & $\begin{array}{c}\text { Extent of following } \\
\text { religious traditions }\end{array}$ \\
\hline Pleasure & $-.35^{*}$ & -.13 \\
\hline Engagement & $.26^{*}$ & $.20^{*}$ \\
\hline Meaning & -.13 & -.11 \\
\hline
\end{tabular}

Note. $* \mathrm{p}<.05$.

Source: Authors' computation 


\section{Discussion}

The aim of the study was to make a cultural adaptation of Orientation to Happiness Scale for Ukrainian-speaking respondents. Following this aim, a double-translation of the 18item English parent form was made, 468 Ukrainian speakers were polled with the translated version and psychometric properties were evaluated.

The three-factor structure of the orientation to happiness concept was retrieved after a procedure of EFA. A number of adaptation researches in other cultures (in Turkish (Saricam and Canatan, 2015), in French (Martin-Krumm et al., 2015), in German (Ruch et al., 2010) etc.) confirmed a 3-factor model which was proposed by the OTH Scale authors, describing nearly $50 \%$ of total variance (comparing to $53 \%$ of the original version). In our research, $47.8 \%$ of the total variance can be described by a model unless it still remains qualitative enough. There are no cross-loadings found for each of 18 items which means their positions in factors are monosemantic. However, two items have changed positions comparing to where they are located in a parent form.

Item no.9 ("In choosing what to do, I always take into account whether I can lose myself in it") which was originally designed for sub-scale "engagement" after a PCA was found to be connected to other items describing meaning. Item no.17 ("I have spent a lot of time thinking about what life means and how I fit into its big picture") in Peterson et al. (2005) questionnaire was included into "meaning" sub-scale was found to be a part of the factor with other 5 items measuring engagement.

Importantly, that these items were also disputable while other language adaptations were carried out. Working on creation of French version of OTH Scale, Martin-Krumm et al. (2015) received cross-loading of item no.9 in both "engagement" (.505) and "meaning" (.441) sub-scales, thus they decided to exclude it from the questionnaire. On the results of EFA using Turkish version of OTH Scale, Saricam and Canatan (2015) received the lowest loadings for items no. 9 (.29) and no. 17 (.31) among all (there is no information on crossloadings, however), although on the results of CFA the model was taken as quite qualitative and both items were saved.

We decided not to exclude disputable items from the Ukrainian version for a couple of reasons. Firstly, according to Tabachnick and Fidell (2007), components should be excluded from the factor structure if the loading for at least one factor is .40 or less.

Secondly, when having similar situation with items no. 2 (designed for "meaning" but included into "engagement" sub-scale) and no. 4 (designed for "engagement" but included into "pleasure" sub-scale), Martin-Krumm et al. (2015) leave the items in the sub-scales to which they got it according to the current factor analysis. Authors claim that "it is essential not to replicate the original questionnaire "item by item", but to reproduce the theoretical tree-partite construction of the original OTH (Peterson et al., 2005)" (Martin-Krumm et al., 2015, p.266). They explain such results with cultural differences. Numerous researches show such differences of understanding and experiencing happiness (Veerhoven 2010; Lu 2005) and of the concept of orientations to happiness as well.

Namely, Vella-Brodrick et al. (2009) proved that orientation to meaning is more characteristic to American that Australian respondents that are explained by the higher religiosity of the Americans. While comparing Turkish and Russian students, Kose (2014) revealed that three paths to happiness (but meaning even stronger than others) are linked to life satisfaction among Turkish, while for Russians meaning orientation has less 
statistically significant connections with this index of happiness. Kenkyu (2011) stated the absence of significant correlations between the sub-scale "pleasure" and the general life satisfaction among Japanese respondents. It is explained through the role of polar emotions in cultures: for Americans, happiness is associated only with positive emotions, for Japanese both positive and negative but hopeful experiences are basics for being happy.

Comparing social and personal characteristics of Ukrainians and Americans (that were the major sample for parent form adaptation), Hofstede (Hofstede Insights, 2018) stresses that people in the USA are much more individualistic and indulgent and live in social conditions where power distance is less than in Ukraine. On the other hand, Ukrainians tend to avoid uncertainty much more actively than Americans do. All these characteristics may considerably influence a person's positive functioning and orientations to happiness as well.

Thirdly, the results of the reliability tests ( $\alpha$-Cronbach coefficients and retest analysis) are better for the factor structure received while PCA than for proposed in an English parent form. Generally, acceptable reliability properties and high reproductivity of the scale were proved.

Concerning the Ukrainian version of OTH Scale validity, surprisingly, there are not as many statistically significant correlations as it was shown in other culture adaptations. However, the link between happiness and OTH differs much in different researches. Although Peterson, Park, and Seligman (2005) claim that the integral scale ("full life" index) correlates positively with life satisfaction, that is mainly because of strong connections with "pleasure" sub-scale, as orientations to meaning and engagement are its weaker predictors. This means that the cumulative effect appears (Peterson et al., 2005; Avsec et al., 2015; Chan, 2009; Chen et al., 2010). However, according to Schueller and Seligman (2010) meta-analysis, among respondents from 112 countries, the tendency is confirmed that engagement and meaning as paths to happiness are connected to both general indexes of subjective and objective (measured with study and professional achievements) well-being. At the same time, pleasure correlates negatively with those indicators of a happy life.

Big culture diversity of the OTH may be one more possible explanation of the results. Namely, low connectivity of OTH Scale and SWLS can be explained due to the difference in semantics. Henderson et al. (2013) stress that the sub-scale measuring orientation to pleasure does not strongly correlate to hedonistic behaviour which is quite paradoxical. At the same time, the sub-scale measures, not the behaviour itself but an extent to which people are searching and striving for hedonistic pleasure. According to Diener et al. (1985), life satisfaction is a cognitive construct, thus, the path to happiness through momentary pleasures is related more with rational not an emotional evaluation of it. However, emotionality of Ukrainians has deep historical and archetypal background (Blyznyuk and Lepeyko, 2016). That's why such cognitive assessment of happiness is not directly connected with ways to happiness that have hedonistic content.

Engagement and meaning correlate to positive affect. On the one hand, interesting "flow" activity results with emotional satisfaction. On the other hand, such deep existential happiness dimension as the meaning is mainly connected with positive emotions among religious people Vella-Brodrick et al. (2009), thus, it is appropriate to suppose that this result is received because of the fact that more than $1 / 3$ of the sample are religious people.

Positive correlation of orientation to pleasure and negative affect replicates the result of Vella-Brodrick et al. (2009, p. 175). Probably, an intensive search of physical and 
psychological pleasures is a defensive mechanism, e.g. reaction formation or denial, aiming to cope with intro-psychic conflict that is a source of negative emotions.

Concerning links between PWBS and OTH, it is notable that it does not matter what path to happiness a person chooses, this way depends on person's activity on self-development, personal potential realization, desire of becoming a better person (correlation of all OTH sub-scales and "personal growth"). This supports the "full life" hypothesis (Peterson et al., 2005) as the standard of positive functioning. Interestingly, that engagement significantly negatively correlates to environmental mastery which means that people looking for happiness through the "flow" activity do not feel that they control life circumstances, can change it for satisfying personal needs. According to Csikszentmihalyi (2000), flow is actually a state of certain ignorance of the reality for total absorption in the activity that leads to positive feelings in the future and correlates with other subjective well-being indexes (however, mainly retrospectively).

On the results of the current study, it is apt to note that religious orientations, at least selfreports about faith, religiosity, and extent of following religious traditions, cannot be reliable criteria for OTH concept. Generally, no expressive differences between paths to happiness among people with different religious orientations were found. Although the links of subjective well-being and religious orientations were stated by many researchers (e.g., Argyle and Hills, 2000; Lewis et al., 2005), others received no significant correlations (Lewis et al., 2000). According to Allport and Ross (1967), there are two types of religious orientations, extrinsic and intrinsic, caused by different motivational factors. Faith then can be interpreted as an intrinsic aspect of religiosity, which was found to be positively connected with happiness (Lewis et al., 2005), while social (extrinsic) religiosity showed no such links. This can also explain the result that flow more often appears among people who usually visit a church. For faithful people being in a temple, praying, doing other cults is a really meaningful activity that supports concentration, absorption in the personal inner world that is almost equal to Csikszentmihalyi's description of "flow" state: "a clear sense of what has to be done moment by moment; ... an intense concentration of attention; ... exclusion of irrelevant content from consciousness; ... a distortion of the sense of time usually hours pass by in minutes; and a feeling that the activity is intrinsically rewarding, or worth doing for its own sake" (Csikszentmihalyi, 2000, p. 381).

\section{Conclusions}

Certain limitations of the current research should be noted. Firstly, the sex distribution in the sample is not equal. It was created according to the OTH parent scale adaptation sample (Peterson et al., 2005, p. 29), however, the differences between males and females in orientations to happiness were found in further researches (e.g. Brdar, 2009). The future study should be focused on links between OTH subscales and socio-demographic variables. Secondly, some additional statistical procedures (e.g., CFA) can be carried out for testing the three-dimensional model and item locations in the sub-scales. It is possible to find some other structural solutions (like Anić and Tončić (2013) did, describing only two - hedonistic and eudaemonic - orientations, or as Seligman (2011) in his new PERMA model established five dimensions of happiness). Thirdly, in this research, we were not controlling personality variables which may possibly moderate the relations between orientations to happiness and different measures of subjective well-being (Vella-Brodrick et al., 2009). 
However, the Ukrainian translation of Orientation to Happiness Scale generally has acceptable psychometric properties and thus the questionnaire may be used by specialists in wide fields of psychological assessment, either for the researches on topics of happiness and subjective well-being, or for evaluation of client's status on different stages of positive psychology interventions or any other spheres of counselling.

\section{References:}

Allport, G.W., Ross, J.M. (1967): Personal religious orientation and prejudice. Journal of Personality and Social Psychology, 5(4): 423-443.

Anić, P., Tončić, M. (2013): Orientations to Happiness, Subjective Well-being and Life Goals. Psihologijske teme, 22(1): 135-153.

Argyle, M., Hills, P. (2000): Religious experiences and their relations with happiness and personality. International Journal for the Psychology of Religion, 10(3): 157-172.

Avsec, A., Kavčič, T., Jarden, A. (2015): Synergistic paths to happiness: Findings from seven countries. Journal of Happiness Studies, 4(4): 1-20.

Baumeister, R.F., Vohs, K.D. (2002): The pursuit of meaningfulness in life. In: Snyder CR and Lopez SJ (eds) The Handbook of Positive Psychology. New York: Oxford University Press, 608618.

Blyznyuk, T., Lepeyko, T. (2016): Profile of modern Ukrainian manager. Proceedings CrossCultural Business Conference May 19-20, 2016, School of Management, Steyr Campus, 256-266.

Bradburn, N.M. (1969): The structure of psychological well-being. Oxford: Aldine.

Brdar, I. (2009): Approaches to happiness, life goals and well-being. In: Freire T (ed)

Understanding Positive Life: Research and Practice on Positive Psychology. Lisbon: Climepsi Editores, 45-64.

Carli, M., Delle Fave, A., Massimini, F. (1988): The quality of experience in the flow channels: Comparison of Italian and U.S. students. In: Csikszentmihalyi M and Csikszentmihalyi I (eds) Optimal Experience: Psychological Studies of Flow in Consciousness. Cambridge: Cambridge University Press, 288-318.

Chan, D.V. (2009): Orientations to happiness and subjective well-being among Chinese prospective and in-service teachers in Hong Kong. Educational Psychology, 29(2): 139-151.

Chen, L.H., Tsai, Y., Chen, M. (2010): Psychometric analysis of the orientations to happiness questionnaire in Taiwanese undergraduate students. Social Indicators Research, 98(2): 239-249.

Chi, W., Freeman, R., Kleiner, M. (2006): Does changing employers improve job satisfaction? Harvard: Mimeo.

Clark, A. (2006): A note on unhappiness and unemployment duration. Applied Economics Quarterly, 52: 291-308.

Clark, A., Diener, E., Georgellis, Y. et al. (2008): Lags and Leads in Life Satisfaction: a Test of the Baseline Hypothesis. The Economic Journal, 118(529): 222-243.

Csikszentmihalyi, M. (2000): Flow. In: Kazdin AE (ed) Encyclopedia of Psychology. New York: Oxford University Press, 3, 381-382.

Cummins, R.A., Nistico, H. (2002): Maintaining life satisfaction: the role of positive cognitive bias. Journal of Happiness Studies, 3: 37-69.

Danner, D.D., Snowdon, D.A., Friesen, W.V. (2001): Positive emotions in early life and longevity: Findings from the nun study. Journal of Personality and Social Psychology, 80(5): 804-813.

DeNeve, K.M., Cooper, H. (1998): The happy personality: a meta analysis of 137 personality traits and subjective well-being. Psychological Bulletin, 124: 197-229. 
Diener, E., Biswas-Diener, R. (2002): Will Money Increase Subjective Well-Being? A Literature Review and Guide to Needed Research. Social Indicators Research, 57: 119-169.

Diener, E., Emmons, R.A., Larsen, R.J. et al. (1985): The Satisfaction with Life Scale. Journal of Personality Assessment, 49: 71-75.

Diener, E., Sandvik, E., Pavot, W. (2009): Happiness is the frequency, not the intensity of positive versus negative affect. Social Indicators Research Series, 39: 213-231.

Gardner, J., Oswald, A.J. (2006): Do divorcing couples become happier by breaking up? Journal of the Royal Statistical Society, 169: 319-336.

Gomez, V., Allemand, M., Grob, A. (2012): Neuroticism, extraversion, goals, and subjective well-being: Exploring the relations in young, middle-aged, and older adults. Journal of Research in Personality, 46(3): 317-325.

Hayes, N., Joseph, S. (2003): Big 5 correlates of three measures of subjective well-being. Personality and Individual Differences, 34: 723-727.

Henderson, L., Knight, T., Richardson, B. (2013): The hedonic and eudaimonic validity of the Orientations to Happiness scale. Social Indicators Research, 115(3): 1087-1099.

Hofstede Insights (2018): Country Comparison: the USA, Ukraine. Available at: https://www.hofstede-insights.com/country-comparison/ukraine,the-usa/

Horbal, I.S. (2016): Social'no-psychologitchni tchynnyky subiektyvnogo blagopoluccya pensioneriv (Socio-psychological factors of subjective well-being of pensioners): $\mathrm{PhD}$ thesis. Kyiv: Institute for Social and Political Psychology NAES of Ukraine. / Горбаль IC (2016): Соціально-психологічні чинники суб'єктивного благополуччя пенсіонерів : дис. канд. психол. наук. Київ: Інститут соціальної та політичної психології НАПН України.

Hsu, C., Lu, H. (2004): Why do people play on-line games? An extended TAM with social influences and flow experience. Information \& Management, 41(7): 853-868.

Huta, V., Ryan, R.M. (2010): Pursuing pleasure or virtue: The differential and overlapping wellbeing benefits of hedonic and eudaimonic motives. Journal of Happiness Studies, 11(6): 735-762.

Hutz, C.S., Midgett, A., Cerentini, J. et al. (2014): The Relationship of Hope, Optimism, SelfEsteem, Subjective Well-Being, and Personality in Brazilians and Americans, 5: 514-522.

Karskanova, S.V. (2011): Opytuval'nyk "Shkaly psychologitchnogo blagopolutcchya" C. Ryff: process ta rezul'taty adaptatsiyi (Psychological well-being scale by C. Ryff: the process and results of adaptation). Practical psychology and social work, 1, 1-10. / Карсканова СВ (2011): Опитувальник «Шкали психологічного благополуччя» К. Ріфф: процес та результати адаптації. Практична психологія і соціальна робота, 1, 1-10.

Kenkyu, S. (2011): Orientations to happiness in Japanese people: Pleasure, meaning and engagement. The Japanese Journal of Psychology, 81(6): 619-624.

Kiecolt-Glaser, J.K., McGuire, L., Robles, T.F. et al. (2002): Emotions, morbidity, and mortality: new perspectives from psychoneuroimmunology. Annual Review of Psychology, 53(1): 83-107.

Knyazyeva, E.V. (2011): Udovletvorennost' zhyznyu kak socialny fenomen (Life satisfaction as social phenomenon). Journal of Odesa I. Mechnikov National University, 941, 160-165. / Князева ЕВ (2011): Удовлетворенность жизнью как социальный феномен. Вісник Харківського національного університету імені В. Каразіна, 941, 160-165.

Kologryvova, E.I. (2008): Funkciyi osobystisnych pragnen' v perezhyvanni molodoyu lyudynoyu subiektyvnogo blagopoluccya (Functions of personal aspirations in experiencing subjective wellbeing of youth): PhD thesis. Kyiv: Institute for Social and Political Psychology NAES of Ukraine. / Кологривова ЕI (2008): Функції особистісних прагнень в переживанні молодою людиною суб'єктивного благополуччя: дис. канд. психол. наук. Київ: Інститут соціальної та політичної психології НАПН України. 
Kose, I.A. (2014): Psychometric Properties of the Orientations to Happiness Scale and Measurement Invariance Between Samples of Turkish and Russian University Students. Social Indicators Research, 122(3): 945-959.

Lewis, C.A., Maltby, J., Burkinshaw, S. (2000): Religion and happiness: Still no association. Journal of Beliefs and Values, 21(2): 233-236.

Lewis, C.A., Maltby, J. Day, L. (2005): Religious orientation, religious coping and happiness among UK adults. Personality and Individual Differences, 38(5): 1193-1202.

Lu, L. (2005): In Pursuit of Happiness: the Cultural Psychological Study of SWB. Chinese Journal of Psychology, 47(2): 99-112.

Lucas, R.E. (2005): Time does not heal all wounds - a longitudinal study of reaction and adaptation to divorce. Psychological Science, 84: 527-539.

Lucas, R.E., Clark, A.E., Georgellis, Y., et al. (2004): Unemployment Alters the Set Point for Life Satisfaction. Psychological Science, 15(1): 8-13.

Martin-Krumm, C., Kern, L., Fontayne, P. et al. (2015): French Adaptation of the Orientation to Happiness Scale and Its Relationship to Quality of Life in French Students. Social Indicators Research, 124(1): 259-281.

Mascaro, N., Rosen, D.H. (2006): The role of existential meaning as a buffer against stress. Journal of Humanistic Psychology, 46(2): 168-190.

Oishi, S., Schimmack, U., Diener, E. (2001): Pleasures and subjective well-being. European Journal of Personality, 15(2): 153-167.

Peterson, C., Park, N., Seligman, M. (2005): Orientations To Happiness And Life Satisfaction: The Full Life Versus The Empty Life. Journal of Happiness Studies, 6: 25-41.

Peterson, C., Ruch, W., Beermann, B. et al. (2007): Strengths of character, orientations to happiness, and life satisfaction. The Journal of Positive Psychology, 2(3): 149-156.

Park, N., Park, M., Peterson, C. (2010): When is the search for meaning related to life satisfaction? Applied Psychology: Health and Well-Being, 2: 1-13.

Religious Information Service in Ukraine (2018): Religious organizations in Ukraine. Available at: https://risu.org.ua/ua/index/resourses/statistics/ukr_2018/70440/

Ruch, W., Harzer, C., Proyer, R. et al. (2010): Ways to happiness in German-speaking countries: The adaptation of the German version of the Orientations to Happiness questionnaire in paperpencil and internet samples. European Journal of Psychological Assessment, 26: 227-234.

Ryff, C., Keyes, C. (1995): The Structure of Psychological Well-Being Revisited. Journal of Personality and Social Psychology, 69(4): 719-727.

Saricam, H., Canatan, A. (2015): The Adaptation, Validation, Reliability Process of the Turkish Version Orientations to Happiness Scale. Üniversitepark Bülten, 4(1-2): 7-15.

Schimmack, U., Oishi, S., Furr, R.M. et al. (2004): Personality and Life Satisfaction: A FacetLevel Analysis. Personality and Social Psychology Bulletin, 30(8): 1062-1075.

Schueller, S., Seligman, M. (2010): Pursuit of pleasure, engagement, and meaning: Relationships to subjective and objective measures of well-being. The Journal of Positive Psychology:

Dedicated to Furthering Research and Promoting Good Practice, 5(4): 253-261.

Seligman, M. (2011): Flourish. NewYork: FreePress.

Seligman, M. (2002a): Authentic Happiness: Using the New Positive Psychology to Realize Your Potential for Lasting Fulfillment. New York: Free Press.

Seligman, M. (2002b): Positive psychology, positive prevention, and positive therapy. In: Snyder, C. and Lopez, S. (eds) Handbook of positive psychology. New York: Oxford, 3-9.

Seligman, M., Steen, T., Park, N. et al. (2005): Positive psychology progress: Empirical validation of interventions. The American Psychologist, 60(5): 410-421. 
Semkiv, I.I. (2009): Sotsial'ny capital yak tsynnyk gromadyans'koyi aktyvnosti students'koyi molodi: psychologitsna model' (Social capital as a factor of the civil activity of student youth: psychological model): PhD thesis. Kyiv: Institute for Social and Political Psychology NAES of Ukraine. / Семків II (2009): Соціальний капітал як чинник громадянської активності студентської молоді: психологічна модель: дис. канд. психол. н. Київ: Інститут соціальної та політичної психології НАПН України.

Shane, F. (2007): Hedonic treadmill. In: Baumeister, R.F., Vohs, K.D. (eds) Encyclopedia of Social Psychology. Thousand Oaks (California), SAGE Publications, 419-420.

Steger, M.F., Kashdan, T.B., Oishi, S. (2008): Being good by doing good: Daily eudaimonic activity and well-being. Journal of Research and Personality, 42(1): 22-42.

Tabachnick, B.G., Fidell, L. (2007): Using multivariate statistics. Boston: Allyn \& Abacon Edition.

Veerhoven, R. (2010): How Universal is Happiness? In: Diener, E., Helliwell, J.F. and Kahneman, D. (eds) International differences in wellbeing. New York: Oxford University Press, 328-350.

Vella-Brodrick, D.A., Park, N., Peterson, C. (2009): Three Ways to Be Happy: Pleasure, Engagement, and Meaning: Findings from Australian and US Samples. Social Indicators Research, 90(2): 165-179.

Waterman, A.S. (1993): Two Conceptions of Happiness: Contrasts of Personal Expressiveness (Eudaimonia) and Hedonic Enjoyment. Journal of Personality and Social Psychology, 64: 678691.

Zelinska, S.F. (2012): Spivvidnoshennya pokaznykiv subiektyvnogo blagopolutcchya osobystosti z typamy yiyi samovidnoshennya (Interrelation between subjective well-being of personality and types of self-reliance). Journal of Odesa I. Mechnikov National University, Serie Psychology, 17, 8(20): 83-90. / Зелінська СФ (2012): Співвідношення показників суб’єктивного благополуччя особистості з типами iї само відношення. Вісник Одеського національного університету імені І. Мечнікова. Серія Психологія, 17, 8(20): 83-90. 